\title{
Changes in the C:N Ratio in the Sludge Treated with Natural Methods
}

\author{
Józefa Wiater ${ }^{1}$ \\ 1 Department of Technology in Environmental Engineering, Bialystok University of Technology, \\ ul. Wiejska 45E, 15-351 Białystok, Poland \\ e-mail:j.wiater@pb.edu.pl
}

\begin{abstract}
The aim of the study was to evaluate the changes in the carbon/nitrogen ratio as a result of different natural methods of sewage sludge treatment from two municipal wastewater treatment plants. The sludge from the first treatment plant was poured into two lagoons, one covered with reed and the other with willow and a field with Californian earthworms. The sludge from the second treatment plant was composted with sawdust. The sludge processed with each method was simultaneously subjected to Effective Microorganisms. The samples of processed sludge from both treatment plants were collected three times. In the first one, after five weeks, four months and ten months from the beginning of treatment. The material from the second treatment plant was composted after four, ten weeks and a year of composting. In the samples taken, the total nitrogen content was determined by means of the Kjeldahl method. The determination of the organic carbon content was carried out on a TOC analyser. The C: $\mathrm{N}$ ratio was then calculated. It was found that the changes in the $\mathrm{C}: \mathrm{N}$ ratio depended on the duration of individual processes, and to a lesser extent on the way they were processed. The carbon content during sludge processing increased or remained at a similar level and the nitrogen content decreased with time of their processing, regardless of the EM addition. The addition of Effective Microorganisms to the sludge treatment reduced the $\mathrm{C}: \mathrm{N}$ ratio in the first period of time and increased this ratio to the optimal value after 10 months or a year. The best technology for sludge processing appeared to be the technology of heap composting with sawdust and with aeration. The ten-week compost had a suitable $\mathrm{C} / \mathrm{N}$ ratio for use in lawn production.
\end{abstract}

Keywords: carbon, nitrogen, sludge, processing.

\section{INTRODUCTION}

The Central Statistical Office "Environment Protection 2018" reports that in 2017, about one million tons of dry matter of municipal sewage sludge was produced in the whole country. Wastewater treatment plants have problems with sludge management, the amount of which is still growing due to the increase of older plants being built and modernized. They are looking for the methods of treatment and final disposal of sewage sludge using their own capabilities. The best methods of sludge treatment are those referring to the natural processes, where the waste substances of producers become a substrate for reducers and consumers. Sludge treatment through the use of plants, composting or vermicomposting are biological methods of waste disposal, as they involve biochemical processes, such as those taking place in nature, involving the decomposition of organic matter by re-solidification [Sidełko 2005]. The sewage sludge processed in this way is subjected to multifunctional processes which ensure the stabilisation of the sludge, destruction of pathogenic organisms, weight reduction and hydration. Mazy and lumpy sludge is easily transformed to a less compact consistency under the influence of atmospheric factors, plants and earthworms and in the process of composting with the addition of plant matter [Biernacka, Ozimek 2001 Walkowiak 2007]. However, this method of sludge processing completely eliminates the odour nuisance and reduces or eliminates the presence of pathogenic organisms, as well as decreases (dilutes) the content of heavy metals in the sludge and eliminates pathogenic organisms 
[Jędrczak 2001]. In addition to the disposal of sludge, it is important to reuse it in the economy and environment. After the biological treatment, organic matter can be used as fertiliser, structureforming and reclamation material for degraded soils, as well as in forest management. It can be a valuable organic fertiliser that can replace manure and other organic fertilisers in the establishment and maintenance of urban greenery [Siuta, Wasiak 2009]. The sludge processed in this way is a structure material due to its high carbon, nitrogen and phosphorus content. The value of this material is determined, among other things, by the $\mathrm{C}: \mathrm{N}$ ratio, which should ideally be $25-35: 1$. Insufficient ratio (less than 20) results in the production of an unstable final product, and when it is too high (more than 80) it inhibits the processing and lowers the temperature.

The aim of the study was to evaluate the changes in the carbon/nitrogen ratio as a result of various natural ways of processing the sewage sludge from two municipal wastewater treatment plants in Podlasie.

\section{AREA OF STUDY AND METHODOLOGY}

The first wastewater treatment plant to which wastewater from the district town flows is based on the Biooxyblok system (multifunctional biological reactor). The average amount of wastewater flowing into the plant is $3,500 \mathrm{~m}^{3} /$ day. Excessive raw sludge amounts to about 1 ton of dry matter per day. The sludge generated in the process of wastewater treatment is accumulated in sludge lagoons. Some of the lagoons are covered with reeds and some with willows. After the end of the vegetation period, the reeds are not cut down, but fall down and decompose, enriching the resulting compost and thickening it. A research facility for processing the sludge from the municipal wastewater treatment plant in this facility using energy willow was built at the end of April 2010. Part of the sludge goes to the sludge lagoons and then to a field where it is processed into compost using Californian earthworms. The material from all three installations was subjected to Efficient Microorganisms.

The second wastewater treatment plant receives household wastewater from the district town and industrial wastewater from a dairy and poultry processing plant. It is a mechanicalbiological treatment plant, where the biological part comprises 4 Sequential Biological Reactors (SBR) equipped with a centrifuge, an aeration grate with a compressed air pipeline. Concentrated sludge is pumped to the station for mechanical dewatering of excessive sludge equipped with a filter and belt press. Dehydrated sludge is then transported to the compost preparation building, where it is mixed with sawdust; then, it flows to compost halls and compost maturing halls. On the basis of the sludge in the treatment plant, compost is produced, which is used for lawn production. During its production, the compost was treated with Effective Microorganisms,

The samples of processed sludge from both treatment plants were collected three times. In the first one, five weeks, four months and ten months after the start of treatment. The material from the second treatment plant was used compost after four, ten weeks and a year of composting. In the samples taken, the total nitrogen content was determined using the Kjeldahl method. The determination of the organic carbon content was carried out on a TOC analyser. Then, the C:N ratio was calculated.

\section{RESULTS ANALYSIS AND DISCUSSION}

Tables 1-4 present the results of carbon and nitrogen contents and the carbon/nitrogen ratio calculated on their basis.

Five-week composts were characterised by a very low $\mathrm{C}: \mathrm{N}$ ratio (Table 1). According to Boruszko and Butarewicz [2005], insufficient $\mathrm{C}: \mathrm{N}$ ratio causes the production of unstable compost. Jędrczak [2007] claims that at low carbon values and/or high nitrogen content at a $\mathrm{C}: \mathrm{N}$ ratio

Table 1. Carbon and nitrogen content in $\mathrm{g} / \mathrm{kgd} . \mathrm{m}$. and $\mathrm{C}: \mathrm{N}$ ratio in sludge treated with earthworms

\begin{tabular}{|l|c|c|c|c|c|c|}
\hline \multirow{2}{*}{ Date/Term } & \multicolumn{3}{c|}{ Sludge + earthworm } & \multicolumn{3}{c|}{ Sludge + earthworm + EM } \\
\cline { 2 - 8 } & $\mathrm{C}$ & $\mathrm{N}$ & $\mathrm{C}: \mathrm{N}$ & $\mathrm{C}$ & $\mathrm{N}$ & $\mathrm{C}: \mathrm{N}$ \\
\hline Five weeks & 609 & 77 & 7.9 & 595 & 111 & 5.4 \\
\hline Four months & 681 & 102 & 6.7 & 516 & 100 & 5.2 \\
\hline Ten months & 594 & 33 & 18 & 539 & 23 & 23.4 \\
\hline
\end{tabular}


below 25:1, ammonia may be formed, which is toxic to microorganisms, as a result of which the composting process is stopped. If the nitrogen content is too high, it can be released into the atmosphere, and there can be a smell nuisance. Composting with the California earthworm (vermicompost) resulted in a $\mathrm{C} / \mathrm{N}$ ratio of the 5-week compost and was low after four months. Vermicompost with the addition of Effective Microorganisms contained slightly less carbon, but more nitrogen during this period, resulting in a further reduction in the $\mathrm{C} / \mathrm{N}$ ratio of more than $5: 1$. The ten-month composting period with earthworms significantly improved the $\mathrm{C} / \mathrm{N}$ ratio of $18: 1$. The additional use of Effective Microorganisms significantly increased the $\mathrm{C} / \mathrm{N}$ ratio by more than 5. Other researchers point to the biodegradation of organic matter (including carbon and nitrogen) in the composting and vermicomposting process and indicate different final effects depending on the sewage sludge additives used, as well as the way and length of the process. In Boruszko et al. [2005] during the composting of dairy sludge with various additives, a reduction in organic matter content of $12 \%$ to $27 \%$ was achieved, and Oleszczuk [2006] obtained a $15 \%-20 \%$ organic matter loss for municipal sludge composted with various additives. Jakubus [2010], who studied the composting of municipal sludge with various structural additives and confirmed the organic matter reduction by $10-13 \%$. The process of vermicomposting of sewage sludge indicates a varied efficiency of organic matter decomposition, which is confirmed by the studies conducted for 10 years at the Zambrów WWTP by Boruszko [2016] in mature vermicomposts, where organic matter loss ranged from $21.3 \%$ d.m. to $48.3 \%$ d.m. The studies conducted in Estonia by Haiba et al. [2014] shows a decrease in organic matter content from $63.3 \% \mathrm{DM}$ to $53.9 \% \mathrm{DM}$ in mature vermicompost. Additionally, numerous studies conducted by Kostecka [2000] confirm a reduction in the organic matter content by several dozen to twenty-four percent in the process of vermicomposting of sewage sludge. The studies carried out by Czyżyk and Kozdraś [2004] on the composts from sludge from rural wastewater treatment plants with the addition of straw also showed a low $\mathrm{C} / \mathrm{N}$ ratio after six-month storage of 13.2 and a slightly higher 15.96 after the application of Humobak biopreparation. It can be assumed that the use of Efficient Microorganisms for the composting of sewage sludge with a
California earthworm results in a faster achievement of the required $\mathrm{C} / \mathrm{N}$ ratio and thus a faster maturing of the compost. The composting time has led to a significant reduction in nitrogen content. However, a study of vermicomposts after 6 months by Songin and Hury [2002] showed even lower nitrogen contents of $15.2 \mathrm{~g} / \mathrm{kg}_{\mathrm{d} . \mathrm{m}}$.

The carbon content of the sludge processed in the lagoon with reed increased with time of processing (Table 2). Other dependencies were obtained by Obarska-Pempkowiak et al. [2010], the Ulm study showed a $42 \%$ reduction in organic matter, in reed beds in Helsinge, while in Naskov Valo (Denmark) in the lowest layers of the sediment the amount of organic matter was 36.6\%-41.3\% [Kołecka and Obarska Pempkowiak 2013]. In the study, the opposite relationship was observed for nitrogen, regardless of the EM presence. The $\mathrm{C} / \mathrm{N}$ ratio in the first and second term was low and exceeded 5:1. In a reed facility, however, the use of Effective Microorganisms resulted in a significant expansion of the $\mathrm{C} / \mathrm{N}$ ratio. The reason was a significant reduction in the nitrogen content, which most probably was used by the present microorganisms and escaped in the form of oxides. According to Sidełko [2005], the physically and chemically different areas inside the compost mass are conducive to different transformations of ammonium nitrogen, mainly in the process of biosynthesis and sorption, as well as oxidation and reduction to mineral forms easily carried away with leachate or process gas. This leads to a systematic reduction in the amount of nitrogen in relation to its initial content. Sidełko [2005] refers to the Tiquia and Tama studies, which observed even $58 \%$ decrease in the nitrogen content during the sediment transformation processes. Nielsen et al.[2002], stress that 50\%$90 \%$ of total nitrogen in the sediment occurs in the form of organic nitrogen and one of the reasons for the decrease in nitrogen content in the sediment is the biodegradation of organic matter and the ammonification process. The decrease of the nitrogen content in stabilised sediments in reed and willow deposits is also influenced by the occurrence of nitrification and denitrification processes. Additionally, high nitrogen accumulation by reeds and willows described by Kadlec and Walace [2009], Obarska-Pempkowiak [2010] and others, was also indicated. However, the content of organic carbon after six-month composting was $307.3 \mathrm{~g} / \mathrm{kg}$ d.m. and after one year $-268.4 \mathrm{~g} / \mathrm{kg}$ d.m. In the above mentioned studies, the nitrogen 
Table 2. Carbon and nitrogen content in $\mathrm{g} / \mathrm{kg}$ d.m. and C:N ratio in the sludge treated with reeds

\begin{tabular}{|l|c|c|c|c|c|c|}
\hline \multirow{2}{*}{ Date/Term } & \multicolumn{3}{|c|}{ Sludge + reed } & \multicolumn{3}{c|}{ Sludge + reed + EM } \\
\cline { 2 - 7 } & $\mathrm{C}$ & $\mathrm{N}$ & $\mathrm{C}: \mathrm{N}$ & $\mathrm{C}$ & $\mathrm{N}$ & C:N \\
\hline Five weeks & 476 & 71 & 6.7 & 533 & 104 & 5.1 \\
\hline Four months & 524 & 107 & 5.2 & 519 & 95 & 5.5 \\
\hline Ten months & 681 & 36 & 16.6 & 681 & 36 & 18.9 \\
\hline
\end{tabular}

Table 3. Carbon and nitrogen content in $\mathrm{g} / \mathrm{kg}$ d.m. and $\mathrm{C}: \mathrm{N}$ ratio in the sludge treated with willow

\begin{tabular}{|l|c|c|c|c|c|c|}
\hline \multirow{2}{*}{ Date/Term } & \multicolumn{3}{|c|}{ Sludge + willow } & \multicolumn{3}{c|}{ Sludge + willow + EM } \\
\cline { 2 - 7 } & C & N & C:N & C & N & C:N \\
\hline Five weeks & 519 & 118 & 4.4 & 578 & 84 & 6.9 \\
\hline Four months & 620 & 102 & 6.1 & 409 & 109 & 3.7 \\
\hline Ten months & 768 & 37 & 20.8 & 697 & 37 & 18.8 \\
\hline
\end{tabular}

Table 4. Carbon and nitrogen content in $\mathrm{g} / \mathrm{kg}$ d.m. and $\mathrm{C}: \mathrm{N}$ ratio in the composted sawdust sludge

\begin{tabular}{|l|c|c|c|c|c|c|}
\hline \multirow{2}{*}{ Date/Term } & \multicolumn{3}{c|}{ Sludge + sawdust } & \multicolumn{3}{c|}{ Sludge+sawdust +EM } \\
\cline { 2 - 7 } & $\mathrm{C}$ & $\mathrm{N}$ & $\mathrm{C}: \mathrm{N}$ & $\mathrm{C}$ & $\mathrm{N}$ & C:N \\
\hline Four weeks & 597 & 97 & 6.2 & 730 & 102 & 7.2 \\
\hline Ten weeks & 812 & 58 & 14 & 720 & 50 & 14 \\
\hline Twelve months & 768 & 37 & 20.8 & 697 & 30 & 23 \\
\hline
\end{tabular}

losses in the case of sewage sludge with reed and EM were even $83 \%$, compared to 5 -week processing. The $\mathrm{C}: \mathrm{N}$ ratio in 10 -month composts was similar to that of digested manure $(20: 1)$.

The carbon content of the sludge on the lagoon with willow (Table 3) increased with the processing time of the sludge without EM and the nitrogen decreased. The greatest decrease in the nitrogen content occurred in the sludge after 10 months of processing. The addition of EM resulted in a decrease in the carbon content four months after their application and a further increase after 10 months. A similar dependence was found for nitrogen. The $\mathrm{C}: \mathrm{N}$ ratio increased in the sludge without EM reaching 20.8 after 10 months of processing. After the addition of EM to the sludge, the ratio was variable; in the second period of time it decreased almost by half and after 10 months it increased to 18.8. Czekała and Sawicka [2006] claim that it is difficult to achieve an optimal $\mathrm{C} / \mathrm{N}$ ratio at the beginning of sludge treatment. They also recall the studies by Czyżyk and others [2001] as well as Krzywe and others [2002], which confirm this fact. The above mentioned authors claim that the reason for this is the high nitrogen content in sludge and that an intensive decomposition of organic matter should be expected in the treatment processes.

The carbon content of composted sludge changed slightly over time (Table 4). In the
EM-free composts, the carbon content increased after ten weeks of composting compared to the previous deadline. After one year of composting, the carbon content decreased by several dozen grams. According to Mazury and Masuria [2009], the compost from municipal sludge with the addition of tree leaves that they examined contained $25.2 \mathrm{~g} / \mathrm{kg}_{\mathrm{d} . \mathrm{m}}$. of nitrogen and $316 \mathrm{~g} / \mathrm{kg}_{\text {d.m. }}$ of organic carbon. In the composts studied by them, the obtained $\mathrm{C} / \mathrm{N}$ ratio was 12.5. After the addition of EM, the carbon content initially increased and decreased over the composting time. The loss of nitrogen in the composts with plant additives is shown in Krzywy et al [2002] and Czyżyk et al. The nitrogen content was in the range of $23.3-18.6 \mathrm{~g} / \mathrm{kg}_{\mathrm{d} . \mathrm{m}}$. (after half-year and two-year processing, respectively), while the loss of carbon was small and amounted to $307.3 \mathrm{~g} / \mathrm{kg}$ and $268.4 \mathrm{~g} / \mathrm{kg}_{\text {d.m.. }}$ respectively. Similar dependencies were obtained by other researchers (Haroun et al. 2007, Haiba et al. The addition of EM has contributed to an increase in the $\mathrm{C}: \mathrm{N}$ ratio after one year of composting. Heo et al. [2008] claims on the basis of his research that the addition of EM in the composting process of organic waste significantly affects the ability to increase the maturity of the compost, faster reduction of odours and stabilisation of the mature compost, as well as allows a higher degree of nitrogen fixation 
in the soil. The positive influence of the use of EM on the speed of the composting process and the quality of the obtained composts was also demonstrated by others [Sivasubramanian and Namasivayan 2013, Czyżyk and Kozdraś 2004]. On the other hand, Czekała [2013] and Jakubus [2010] have not found any positive influence of the EM application on the quality of the sewage sludge compost obtained and its processing speed. The Mazur and Mazur [2009] studies indicate the nitrogen content in composts with the addition of sawdust equal to $22.2 \mathrm{~g} / \mathrm{kg} \mathrm{d} . \mathrm{m}$. The addition of sawdust may significantly improve the $\mathrm{C} / \mathrm{N}$ ratio due to high carbon content and low nitrogen content. They state that the organic carbon content of composts with added sawdust is $398 \mathrm{~g} / \mathrm{kg}$ d.m. and the $\mathrm{C} / \mathrm{N}$ ratio is $17.4: 1$. The above studies indicate a much lower $\mathrm{C} / \mathrm{N}$ ratio at the beginning of the composted period. It can be concluded that the microorganisms themselves were also an additional source of nitrogen. The composts in this state cannot be used for natural purposes due to an inappropriate $\mathrm{C} / \mathrm{N}$ ratio. The compost must continue to mature for at least one year. Similar results were obtained by Górska and others [2009] after two years of composting the sludge with pine sawdust. The results varied depending on the thickness of sawdust. Such mature compost can be successfully used as a substrate for lawn production, as is the case in the second wastewater treatment plant studied.

\section{CONCLUSIONS}

1. The $\mathrm{C} / \mathrm{N}$ ratio in sludge treatment has changed significantly mainly due to the sludge treatment and - to a lesser extent - as a result of the treatment method.

2. The carbon content during sludge treatment increased or remained at similar levels and the nitrogen content decreased over the treatment time regardless of the EM addition.

3. The addition of Effective Microorganisms to the processed sludge in the first period lowered the ratio of $\mathrm{C}: \mathrm{N}$, and after 10 months or a year increased this ratio to an optimal level.

4. The best technology for processing the sludge proved to be the technology of heap composting it with sawdust and with aeration. The tenweek compost had a suitable $\mathrm{C} / \mathrm{N}$ ratio for use in lawn production.

\section{REFERENCES}

1. Biernacka E., Ozimek T. 2001. Sludge drying with reed application of Phragmites australis. Scientific Journals of the Faculty of Construction and Environmental Engineering. Technical University of Koszalin, 20, 247-252.

2. Boruszko D., Butarewicz A. 2005. Research on the final use of dehydrated sewage sludge for nonindustrial use. Bialystok University of Technology, Bialystok, 104.

3. Boruszko D. 2016. Determining the effectiveness in vermicomposting of sewage sludges and the attempt to increase the effectiveness by applying bacterial microorganisms. Journal of Ecological Engineering, 17(3), 53-59.

4. Czekała J., Sawicka A. 2006. Processing of sewage sludge with the addition of straw and sawdust into an environmentally safe product. Water-Environment-Rural Areas, 2, t.6, z.2 (18), 41-50.

5. Czekała J. 2013. Dynamics of changes of carbon and nitrogen compounds in the composting process of pine bark. Journal of Resarch and application in Agricultural Engineering, 58(3), 81-85.

6. Czyżyk F., Kuczewska M., Sieradzki T. 2001. Preliminary results of the research on composting liquid sewage sludge with straw. Problematic Advances in Agricultural Sciences, 475, 263-269.

7. Czyżyk F., Kozdraś M. 2004. Chemical properties and composting of sludge from rural wastewater treatment plants. Water - Environment - Rural areas, 4(2a), 559-569.

8. Górska E.B., Stępień W., Gozdowski D., Gabara M., Trzciński P. 2009. Impact of the type of composted organic waste on the quality of composting. Environmental Protection and Natural Resources, 40, 586-591.

9. Haiba E., Ivask M., Olle L., Peda J., Kuu A., Kutti S., Nei L. 2014. Transformation of Nutrients and organic matter in vermicomposting of sewage sludge and kitchen wastes. Journal of Agricultural Science, 6(2), 114-120.

10. Haroun M., Idris A., Syed Omar S.R. 2007. Characterisation and composting of tannery sludge. Malaysian J. Soil Sci, 11, 71-80.

11. Heo S.-U., Moon S.-Y., Yoon Ki-S., Kim Y.-J., Koo Y.-M. 2008. Enhanced compost maturity by effective microorganisms. Journal of Biotechnology, 136, 22-71.

12. Jakubus M. 2010. Changes in speciation and bioavailability of microelements during composting of sewage sludge with different bio-waste. Scientific Dissertations No. 404, Poznań University of Life Sciences.

13. Jędrczak A. 2001. Biological waste treatment. Municipal Review, 6(117), 89-92. 
14. Jędrczak A. 2007. Biological treatment of waste. PWN Scientific Publishers, Warsaw.

15. Kadlec R.H. and Wallace S.D. 2009. Treatment wetlands. Second edition, CRS Press, Taylor and Francis Group.

16. Kołecka K., Obarska-Pempkowiak H., 2013. Potential fertilizing properties of sewage sludge treated in the Sludge Treatment Reed Beds (STRB). Water Science \&Technology, 68(6), 1412-1418.

17. Kostecka J. 2000. Research on vermicomposting of organic waste. Zesz. Nauk. AR Krakow, Series of Theses, 268, 88.

18. Krzywy E., Wołoszczyk Cz., Iżewska A., Krzywy J.,2002. Processing of sewage sludge with added straw and sawdust into a product safe for the environment. Acta Agrophys., 70, 217-223.

19. Mazur Z., Mazur T.2009. Agrochemical evaluation of composts produced on the basis of municipal sewage sludge. Problematic Notebooks on the Progress of Agricultural Sciences, 535, 277-282.

20. Nielsen S. 2002. Sludge drying reed beds. Proceedings of the 8th International Conference on Wetland systems for Water Pollution Control. Vol. I, Arusha International Conference Centre (AICC), University of dear Salaam, 24-39.

21. Obarska-Pempkowiak H., Tuszyńska A. 2002. Disposal of sewage sludge in reed beds, 1 st Congress of Environmental Engineering, Monographs of the
Committee of Environmental Engineering of the Polish Academy of Sciences, 12(33), 341-360.

22. Obarska-Pempkowiak H., Gajewska M., Wojciechowska E. 2010. Hydrophytic treatment of water and waste water. PWN, Warszawa.

23. Oleszczuk P. 2006. Influence of different bulking agents on the disapparance of PAHs during sewage sludge composting. Water, Air and Soil Pollution, $175,15-32$.

24. Sidełko R. 2005. Composting: process optimization and product quality forecast. Koszalin University of Technology, Koszalin, Poland

25. Siuta J., Wasiak G., 2009. Composting and use of compost, Materials of the 1st Scientific and Technical Conference, Puławy-Warsaw, 129.

26. Sivasubramanian S., Karthick Raja Nama Sivayam S. 2013. Evaluation of phenol degradation by effective microorganism (EM) technology with EM-1. African Journal of Microbiology Research, 7 (32), 4117-4122.

27. Songin H., Hury G. 2002. Changes in the chemical composition of composts and vermicomposts produced on the basis of sewage sludge. Problematic Notebooks on the Progress of Agricultural Sciences 484, 589-594.

28. Walkowiak A. 2007. Impact of selected environmental parameters on vermicomposting of sewage sludge. Polish Journal of Natural Sciences, 22(1), 84-91. 